\title{
Strengthening Character In The Teaching Campus Program At The Jaya Negara Elementary School, City Of Makassar
}

\author{
Suardi ${ }^{1)}$, Syahban Nur ${ }^{2)}$ \\ Sociology Education Study Program, Faculty of Teacher Training and Education, University of \\ Muhammadiyah Makassar, Sultan Alauddin No. 259, Makassar, Indonesia 90221 \\ Corresponding Author: Suardi, Email: suardi@unismuh.ac.id
}

History: Received 14/12/2021 | Revised 15/12/2021 | Accepted 24/12/2021 | Published 31/01/2022

\begin{abstract}
The Independent Learning Activity-Independent Campus (MBKM) is the success of national education and a forum for character strengthening for students. This type of research is descriptive qualitative research through a case study approach. The research instrument is the researcher himself conducts interviews, observations, and documentation. The data collected is then analyzed through data reduction, data presentation, and concluding. Validation of the data is done through technical triangulation. The results of the study show that Merdeka Learning-Independence Campus (MBKM) helps the teaching and learning process at the elementary school level by involving students in the teaching and learning process, providing strengthening of the character of students such as the character of reading, critical reasoning, social care, cooperation, curiosity and disciplined character.
\end{abstract}

Keywords: Character Strengthening, Independent Learning-Independent Campus (MBKM), Teaching Campus

\begin{abstract}
Abstrak. Kegiatan Merdeka Belajar-Kampus Merdeka (MBKM) bukan hanya mensukseskan pendidikan nasional namun juga sebagai wadah penguatan karakter untuk peserta didik. Jenis penelitian adalah penelitian deskriptif kualitatif melalui pendekatan studi kasus. Instrumen penelitian adalah peneliti sendiri melakukan wawancara, observasi dan dokumentasi. Data yang dikumpulkan kemudian dianalisis melalui tahapan reduksi data, penyajian data, menarik kesimpulan. Pengabsahan data dilakukan melalui triangulasi teknik. Hasil penelitian menunjukan Merdeka Belajar-Kampus Merdeka (MBKM) membantu proses belajar mengajar di jenjang sekolah dasar dengan melibatkan mahasiswa dalam proses belajar mengajar memberikan penguatan terhadap karakter peserta didik seperti karakter gemar membaca, bernalar kritis, peduli sosial, gotong royong, rasa ingin tahu dan karakter disiplin.
\end{abstract}

Kata kunci: Penguatan Karakter, Merdeka Belajar-Kampus Merdeka (MBKM), Kampus Mengajar 


\section{INTRODUCTION}

Students are the next generation of parents on a micro basis and are the nation's next generation. The development of Indonesia in the future as a country will depend on the quality of students. This is one of the first steps in preparing the quality of human resources who have knowledge and skills and have morality, character, values , and character. However, seeing the condition of education in Indonesia continues to strive to improve the quality of education even though the level of education in Indonesia needs to be improved, both in urban areas that have educational progress and cities that do not yet have good academic progress (Zahroh \& Pontoh, 2021).

Improving the quality of education in Indonesia then encountered new challenges in early 2020 when the Corona Virus Diseases 19 (Covid-19) pandemic occurred. The Covid-19 pandemic situation is a challenge for teachers, especially students, in undergoing and developing the world of education. Through the Ministry of Education and Culture (Kemdikbud), policymakers anticipate the Covid-19 pandemic by implementing Distance Learning (PJJ). Based on the circular letter of the Ministry of Education and Culture No. 40 of 2020, distance learning (PJJ) is an online learning process that can be done at the home of each student in the education unit by utilizing various learning resources for students through information technology
(Mulyana et al., 2020). However, many problems arise in the distance learning process (PJJ), such as uneven access to the internet network, unavailability of device access, affordable quota fees, inconsistent mastery of technology among educators, and others, so the learning process is still experiencing problems. Especially in shaping character with the distance learning process (PJJ).

Another Ministry of Education and Culture program is the Independent LearningIndependent Campus (MBKM) program as a form of adjustment to the development of education during the Covid-19 period (Iriawan \& Saefudin, 2021). One of the Independent Learning-Independent Campus (MBKM) programs is teaching assistance or campus teaching which is expected to be a form of distance learning adjustment (PJJ) in educational units, especially at the elementary school level which still requires a lot of guidance from teachers as direct education personnel.

The Teaching Campus is a part of the Independent Learning-Independent Campus (MBKM) to assist the learning process at the elementary school level (Iriawan \& Saefudin, 2021). Campus teaching involves students from every university in Indonesia with various educational backgrounds. The Teaching Campus Program is considered necessary for the success of national education, especially for students with critical 
conditions and limited access to education during the Covid-19 pandemic.

The purpose of holding a teaching campus program (Iriawan \& Saefudin, 2021) is (1) to provide learning opportunities and student self-development through extraacademic, (2) to provide educational services to students optimally at the elementary school level in limited or critical conditions, (3) Provide optimal learning opportunities for all students.

Campus teaching activities have a close relationship with the character of students, especially in aspects of strengthening the profile of Pancasila, namely (1) faith, fear of God Almighty and noble character, (2) independence, (3) critical reasoning, (4) global diversity, ( 5) cooperation and (6) creative (Iriawan \& Saefudin, 2021).

Based on this explanation, the Independent Learning-Independent Campus (MBKM) activity has an aspect of character strengthening for students, so that students do not fall into behavior that deviates from school and community rules (Suardi, 2018), so that the Independent Learning-Independent Campus (MBKM) ) has an important role in Strengthening Character Education through curricular, co-curricular, extracurricular and non-curricular activities (Suardi, Nursalam, et al., 2020), by providing knowledge, feelings, actions (Kanji et al., 2019b), speech, symbols, habits and a culture of character (Suardi, Nursalam, et al., 2020) (Nur et al., 2021).
Character strengthening can be done starting from elementary school, junior high school, high school to college, to overcome deviations made by students or students (Suardi et al., 2018). Although character strengthening always faces obstacles, school elements can be a supporting factor for strengthening the character of students in elementary schools (Kanji et al., 2020b), in a collaborative design that involves all school elements in shaping the character of students (Suardi, Agustang, et al. ., 2020), such as teachers, principals, students, lecturers, and parents.

\section{RESEARCH METHODS}

This study used qualitative descriptive research through a case study approach and a post-positivistic paradigm (Nursalam et al., 2016) at the Jaya Negara elementary school, City of Makassar. The researcher himself used the research instrument as the main instrument and used interview instruments, observation instruments, and documentation instruments. The selection of informants by purposive sampling followed the focus of the research, namely character strengthening in the campus teaching program in elementary schools. In the first stage, the data collection technique was observing, then conducting interviews and documentation at the final step. The data collected was then analyzed through the stages of data reduction, data presentation, concluding after being analyzed, and then checking the correctness of the data obtained 
through data validity techniques through technical triangulation.

\section{DISCUSSION}

Strengthening students' character is contained in the vision and mission of the partners of the Jaya Negara Makassar elementary school education unit, which has an idea of "Generation with noble character, caring, scientific and technological insight, and Indonesian culture." The achievement of the school's vision through the school's mission, namely (1) Instilling a strong aqidah through the practice of religious teachings in forming a generation of believers who are devoted to God Almighty. (2) Implement an active, creative, effective, innovative, fun, and informative learning process to achieve maximum achievement, or student academic achievement (Manda \& Suardi, 2017) (3)

Prepare a generation of achievers who have excellence in the academic field, and nonacademic, with character, noble character, and Indonesian culture. (4) Facilitating students mastering science and technology to have superior competencies in responding to the challenges of the times. (5) Provide motivation, guidance, and activities for each student to recognize their potential so that they can develop optimally. Strengthening religious aspects in the school's vision and mission is part of the formation of the sacred character of students (Suardi et al., 2021).
Jaya Negara Makassar Elementary School is a private school part of the PT. Andika Putra Jaya Negara Makassar is engaged in education and has several levels of education units, including Jaya Negara Kindergarten, Jaya Negara Elementary School, Jaya Negara Junior High School, Jaya Negara High School, Jaya Negara Vocational High School, and others. Jaya Negara Elementary School is located in Balang Baru Village, Makassar City, in an alley and close to local residents' houses. Jaya Negara Elementary School is a school in the form of a foundation that has other educational levels, such as Kindergarten, Elementary School, Junior High School, Senior High School, Vocational High School, and Packages A, B, and C. All levels of education are led by the head M. Abdullah S Haq Lc school. During the pandemic, the building used for learning and administrative management was the Jaya Negara High School Building.

Jaya Negara Elementary School is one of the schools with $\mathrm{C}$ accreditation in Makassar. Jaya Negara Elementary School has 6 study groups, with details of one study group at each grade level. The number of students at Jaya Negara Elementary School is 161 students with the following details: (a) 20 students in grade 1; (b) 19 students in grade 2; (c) There are 26 students in grade 3; (d) There are 25 students in grade 4; (e) There are 34 students in grade 5; and (f) Class 6 students totaled 37 people. Nine teachers and one 
teaching staff taught the learning group at the Jaya Negara Elementary School.

During the pandemic, Jaya Negara Elementary School carried out complete online learning; through the learning process in every subject, the teacher formed students' character (Suardi et al., 2019). However, not all students have access to the internet or gadgets in online learning activities because sometimes they need to use their parents' devices. Still, on the other hand, their parents also need to go to work, so the alternative made by the principal is to call students to come to school to take assignments and then take them home. However, teachers are also not allowed to teach in the form of house-tohouse visits because parents do not like to be intervened at home. Therefore the program of activities carried out adapts to the conditions of the school, teachers, students, and parents of students.

Various work programs are carried out by the Independent Learning-Independence Campus (MBKM) activities such as let's read, small groups, reading corners, administrative assistance, and technology adaptation. However, in practice, let's read work programs! And Small groups are not as scheduled because the learning carried out is online learning. There is very little time together with students even though the school appealed to students to take offline learning at school with students by complying with health protocols. Although offline learning at school is not mandatory for students, not all students come to study offline at school. This condition impacts the work program schedule that students have planned. In offline learning at school, students provide learning that focuses on literacy and numeracy at the elementary level according to the elementary school level. So the work program, let's read! and Small groups are then applied to each student who comes to study offline at school

Different conditions with the reading corner work program carried out in one of the rooms on the 2 nd floor of the Jaya Negara High School building, held at the end of the teaching campus program due to funding constraints. The reading corner program is expected to increase students' interest in literacy by providing reading books such as non-fiction books in the form of knowledge, children's novels, and textbooks available at school.

\section{Let's Read!}

This activity is group learning by emphasizing meaningful literacy learning for students. This activity is carried out every two days a week attended by students of Jaya Negara Elementary School Grades one to three even though it's from the Let's Read! It was found that there were still early grade students (1) still unable to read fluently, (2) not being able to distinguish letters with the same characteristics, such as letters b and d, letters $\mathrm{m}$ and $\mathrm{n}$, (3) unable to draw conclusions and 
find ideas the main paragraph of the text provided.

However, in the Program Ayo Membaca, students are invited to read together and have discussions related to reading so that their interest in reading is more visible than before. Discussion is a suitable method for improving student learning outcomes (Suardi \& Kanji, 2018) (Suardi, 2017). This is evidenced by the students who asked permission to read together without being directed. Reading activities can reinforce the character of reading fondness, namely, reading habits that benefit students (Nursalam et al., 2020). By reading, students try to obtain and process information to solve problems in learning which is an indicator of critical reasoning character. (Iriawan \& Saefudin, 2021).

\section{Small-Group}

This activity is learning in groups on a small scale to help students achieve the expected learning outcomes according to the class level of students. Group activities can substantially improve student learning outcomes (Kanji et al., 2018). This activity is carried out every two days a week, attended by students of Jaya Negara elementary school grades one to six. However, lower-grade students are still not fluent in adding and sometimes miswriting numbers. However, through small group activities, students explain the concept of adding units and tens to lower grade students and teach the concept of simple fractions by imagining surrounding objects. In contrast, upper-grade students are given tens multiplication learning through flashcards and other learning media in the form of numbers.

Small group activities strengthen students' friendly and communicative character because through these activities, students show a sense of pleasure in talking and collaborating with other students. In addition, small group activities also provide strengthening of the social care character (Kanji et al., 2020a) to students because students show attitudes or behaviours of students who always want to help other students in their small groups (Nursalam et al., 2020), in groups, students collaborate in learning, have concern for group members in sharing information and learning experiences, this is by the indicators of the character of gotong royong (Iriawan \& Saefudin, 2021).

\section{Reading Corner}

This activity is an effort to create access to reading books and improve student literacy. This activity will be carried out once in a mini library to enhance all students' literacy in Jaya Negara elementary school. Reading activities can reinforce the character who likes to read, namely the habit of reading that benefits students (Nursalam et al., 2020). Through the reading corner, students try to obtain and process information to solve 
problems in learning which is an indicator of the character of critical reasoning (Iriawan \& Saefudin, 2021).

\section{Technology Adaptation}

The technology adaptation work program through Canva is a training to use the Canva website and application in designing engaging learning media for all teachers at Jaya Negara elementary schools. This activity will be held once in education about the Canva application. However, the work program in this area consists of Canva-in. The Independent Learning-Independent Campus (MBKM) activity strengthens the creative character of teachers because, in the activities, the teacher does not only think but also create something new, namely interesting learning media for students through the Canva application. Media can be a means of forming students' character in learning (Suardi \& Nursalam, 2020) (Suardi \& Syarifuddin, 2018), so to attract students' attention to the media used, the media used must be innovative and creative (Israpil \& Suardi, 2021) In addition, this activity strengthens the teacher's curiosity character because the teacher shows attitudes and actions that want to know more deeply about the Canva application that has been studied and practised (Nursalam et al., 2020).

\section{Administrative Assistance}

This activity is carried out to assist every administrative need of the Jaya Negara elementary school to meet the organisational needs of students and teachers. Activities are carried out by adjusting the needs of the Jaya Negara elementary school. The work program in this field assists every administrative requirement for the Jaya Negara elementary school. This program runs well as long as the campus teaching program lasts. The forms of administration that are carried out include entering report cards into the application, writing letters, compiling lesson plans, and compiling learning assessments. Assessment is an essential aspect that teachers must understand to evaluate student learning outcomes, including evaluation of student character education (Kanji et al., 2019a). The Independent Learning-Independence Campus (MBKM) activity has provided a strengthening of the disciplined character of teachers and students because in these activities both teachers and students demonstrate orderly behavior and obey the rules that apply at Jaya Negara elementary school, including the school administration rules that apply to teachers, students.

The idea of an Independent LearningIndependent Campus (MBKM) Minister of Education and Culture (Mendikbud) in producing superior Human Resources (HR) by prioritizing the implementation of character values (Widiyono et al., 2021), developing insight, character and soft skills of students and understanding the character of students (Anugrah, 2021) (Khotimah et al., 2021), 
providing opportunities for students to hone their character, for students to be able to shape character education and form a profile of Pancasila students (Anwar, 2021) or improve the character of students (Fauzi et al., 2021).

\section{CONCLUSION}

Teaching Campus is one part of the Merdeka Campus program to assist the teaching and learning process at the elementary school level, which involves students in the teaching and learning process providing strengthening of the character of students such as the character of reading, critical reasoning, social care, cooperation, curiosity and disciplined character.

\section{REFERENCES}

[1] Anugrah, T. M. F. (2021). Implementasi Pelaksanaan Program Kampus Mengajar Angkatan 1 Terdampak Pandemi Covid-19. AKSELERASI: Jurnal Ilmiah Nasional, 3(3), 38-47. https://doi.org/10.54783/jin.v3i3.458

[2] Anwar, R. N. (2021). Pelaksanaan Kampus Mengajar Angkatan 1 Program Merdeka Belajar Kampus Merdeka di Sekolah Dasar. Jurnal Pendidikan Dan Kewirausahaan, 9(1), 210-219.

https://doi.org/10.47668/pkwu.v9i1.221

[3] Fauzi, T. I., Astuti, N. P., \& Rahmawati, D. N. U. (2021). Program Kampus Mengajar (Pkm) Sebagai Usaha Peningkatan Pembelajaran Peserta Didik Di Sdn 127 Sungai Arang, Bungo Dani, Kabupaten Bungo, Provinsi Jambi. Jurnal BUDIMAS, 03(02), 483-490.

[4] Iriawan, S. B., \& Saefudin, A. (2021). Buku Saku Utama Aktivitas Mahasiswa Program Kampus Mengajar 2021. Kementrian Pendidikan Dan Kebudayaan 2021, 37.

[5] Israpil, \& Suardi. (2021). The Innovation and
Creativity of Religious Moderation Learning Through Sociology Learning and Pancasila and Citizenship Education in Public Schools and Madrasas Gorontalo City. JED (Jurnal Etika Demokrasi), 6(2), 232-242. https://doi.org/https://doi.org/10.26618/jed.v $\underline{6 i 1.4692}$

[6] Kanji, H., Amin, B., Syakur, A., \& Suardi, S. (2018). PENINGKATAN HASILBELAJAR BAHASA INDONESIA MELALUI MODEL PEMBELAJARAN KOOPERATIF TIPE NUMBERED HEADS TOGETHER. JRPD (Jurnal Riset Pendidikan Dasar), 1(1), 25-33.

https://doi.org/10.26618/jrpd.v1i1.1236

[7] Kanji, H., Nursalam, N., Nawir, M., \& Suardi, S. (2019a). Evaluasi Integrasi Pendidikan Karakter dalam Pembelajaran Ilmu Pengetahuan Sosial di Sekolah Dasar. JED (Jurnal Etika Demokrasi), 4(2), 56-63. https://doi.org/10.26618/jed.v4i2.2386

[8] Kanji, H., Nursalam, N., Nawir, M., \& Suardi, S. (2020a). INTEGRATION OF SOCIAL CARE CHARACTERS AND MORAL INTEGRATIF ON SOCIAL SCIENCE LESSONS IN ELEMENTARY SCHOOL. AL-ISHLAH: Jurnal Pendidikan, 12(2), 413-427. https://doi.org/10.35445/alishlah.v12i2.260

[9] Kanji, H., Nursalam, Nawir, M., \& Suardi. (2019b). Model Integrasi Pendidikan Karakter dalam Pembelajaran Ilmu Pengetahun Sosial di Sekolah Dasar. Jurnal Pendidikan Dasar Perkhasa , 5(2), 104-115. https://doi.org/10.31932/jpdp.v5i2.458

[10] Kanji, H., Nursalam, Nawir, M., \& Suardi. (2020b). Supporting and Inhibiting Factors of Character Education in Learning Social Studies at Primary Schools. JED (Journal of Etika Demokrasi), 5(1), 1-14. https://doi.org/10.26618/JED.V5I1.2966

[11] Khotimah, N. R., Riswanto, \& Udayati. (2021). PELAKSANAAN PROGRAM KAMPUS MENGAJAR DI SD NEGERI 014 PALEMBANG SUMATERA SELATAN Pandemi Covid-19 yang menyerang berbagai Negara termasuk Indonesia telah ( MBKM ) yang memberikan hak belajar mahasiswa selama tiga semester di luar program studi pandemi, te. Sinar Sang Surya ( Jurnal Pusat Pengabdian Kepada Masyarakat ), 5(2), 
194-204.

[12] Manda, D., \& Suardi, S. (2017). Status Sosial Orang Tua dan Prestasi Akademik Siswa. Equilibrium: Jurnal Pendidikan, 4(2), 194202.

https://doi.org/10.26618/equilibrium.v4i2.50 $\underline{1}$

[13] Mulyana, Siagian, N., Basid, A., Saimroh, Sovitriana, R., Habibah, N., Saepudin, J., Maimunah, M. A., Muaripin, \& Oktavian, C. N. (2020). Pembelajaran Jarak Jauh Era Covid-19. In Litbangdiklat Press. www.balitbangdiklat.kemenag.go.id

[14] Nur, R., Suardi, Nursalam, \& Kanji, H. (2021). Integrated Model of Character Education Development Based on Moral Integrative to Prevent Character Value Breaches. AL-ISHLAH: Jurnal Pendidikan, 13(1), 107-116. https://doi.org/10.35445/alishlah.v13i1.272

[15] Nursalam, Nawir, M., Suardi, \& Kanji, H. (2020). MODEL PENDIDIKAN KARAKTER PADA MATA PELAJARAN ILMU PENGETAHUAN SOSIAL DI SEKOLAH DASAR (Vol. 1). CV. AA. RIZKY. https://books.google.co.id/books?hl=id\&lr= $\& \mathrm{id}=8 \mathrm{tUKEAAAQBAJ} \&$ oi $=$ fnd $\&$ pg $=$ PA63 $\& d q=$ buku+suardi+nursalam+pendidikan+ka rakter\&ots $=1 \mathrm{~A}--$

g2fQs4\&sig=zVhj4kYePdGJVf09G419nxFs$\mathrm{H} 4 \&$ redir_esc $=\mathrm{y} \# \mathrm{v}=$ onepage \&q=buku suardi nursalam pendidikan karakter $\& \mathrm{f}=$ false

[16] Nursalam, Suardi, \& Syarifuddin. (2016). Teori Sosiologi Klasik, Modern, Posmodern, Saintifik, Hermeneutik, Kritis, Evaluatif dan Integratif (Muhammad A). Writing Revolution.

[17] Suardi. (2017). Peningkatan Hasil Belajar Sosiologi Pokok Bahasan Interaksi Sosial Melalui Metode Diskusi pada Siswa Kelas X MA. Muhammadiyah Panaikang Kacamatan Bissappu Kabupten Bantaeng. Jurnal Etika Demokrasi Pendidikan Pancasila Dan Kewarganegaraan, II(1), 2339-2401. https://doi.org/10.26618/JED.V2I1.1145

[18] Suardi. (2018). SOSIOLOGI KOMUNITAS MENYIMPANG (Vol. 1). Writing Revolution.

https://books.google.co.id/books?id=F9kKE AAAQBAJ\&printsec $=$ frontcover $\& \mathrm{dq}=$ SOSI
OLOGI+KOMUNITAS+MENYIMPANG\&

$\mathrm{hl}=\mathrm{id} \& \mathrm{sa}=\mathrm{X} \& \mathrm{ved}=2 \mathrm{ahUKEwinvPjNy}$ DtAh UIX30KHbN8Cc0Q6AEwAHoECAAQAg\# $\mathrm{v}=$ onepage $\& \mathrm{q}=$ SOSIOLOGI KOMUNITAS MENYIMPANG\&f=false

[19] Suardi, Agustang, A., \& Sahabuddin, J. (2020). MODEL KOLABORASI SOSIAL PENDIDIKAN KARAKTER DI SEKOLAH SWASTA KECAMATAN BISSAPPU KABUPATEN BANTAENG. PROSIDING SEMINAR DAN DISKUSI PENDIDIKAN DASAR, 1-11. http://journal.unj.ac.id/unj/index.php/psdpd/a rticle/view/17769

[20] Suardi, \& Nursalam. (2020). Penerapan Model Pembelajaran Saintifik Approach Berbasis Media Classroom. Indonesian Journal of Sociology, Education, and Devolopment, 2(2), 88-97. https://doi.org/https://doi.org/10.52483/ijsed. $\underline{\mathrm{v} 2 \mathrm{i} 2.32}$

[21] Suardi, Nursalam, \& Hasnah, K. (2021). The Integration Model of the Development of Student Religious Character Education Based on Integrative Morals in Higher Education. ... (Journal of Etika Demokrasi), 6(1), 149-162. https://jurnal.unismuh.ac.id/index.php/jed/art icle/view/4692

[22] Suardi, Nursalam, \& Kanji, H. (2020). PENGUATAN PENDIDIKAN KARAKTER: BERBASIS INTEGRATIF MORAL DI PERGURUAN TINGGI (Vol. 1). CV. AA. RIZKY.

https://books.google.co.id/books?hl=id\&lr= \&id=DOADEAAAQBAJ\&oi=fnd $\& p g=$ PA1 $\& d q=b u k u+$ suardi+nursalam+pendidikan+ka rakter\&ots $=\mathrm{aL} 1 \mathrm{dBe} 9 \mathrm{Ue} 3 \&$ sig $=\mathrm{oMu} 7 \mathrm{hsupR}$ OlXcDncIso8LdgI_Oc\&redir_esc $=\mathrm{y} \# \mathrm{v}=$ one page\&q=buku suardi nursalam pendidikan karakter $\& \mathrm{f}=$ false

[23] Suardi, S., Herdiansyah, H., Ramlan, H., \& Mutiara, I. A. (2019). Implementasi Pendidikan Karakter Melalui Mata Pelajaran Pendidikan Kewarganegaraan di SMA Jaya Negara Makassar. JED (Jurnal Etika Demokrasi), 4(1), 22-29. https://doi.org/10.26618/jed.v4i1.198

3

[24] Suardi, S., \& Kanji, H. (2018). Lecture Model of Student Transfer Discussion Method to Increase Student's Activeness and Learning Outcomes. Journal of Educational Science 
and Technology (EST), 4(1),

54.

https://doi.org/10.26858/est.v4i1.4814

[25] Suardi, S., Megawati, M., \& Kanji, H. (2018). Pendidikan Karakter di Sekolah (Studi Penyimpangan Siswa di Mts Muhammadiyah Tallo). JED (Jurnal Etika Demokrasi), 3(1), 75-84.

https://doi.org/10.26618/jed.v3i1.1979

[26] Suardi, \& Syarifuddin. (2018). Penerapan Model Pembelajaran Saintifik Approacd Berbasis Media Pembelajaran Kearifan Lokal pada Mata Kuliah Dasar-Dasar Sosiologi dalam Membangun Karakter dan Meningkatkan Hasil Belajar Mahasiswa Pendidikan Sosiologi Universitas Muhammadiyah Makassar. JED (Jurnal Etika Demokrasi), 3(2), 75-85. https://doi.org/10.26618/jed.v3i2.1627

[27] Widiyono, A., Irfana, S., \& Kholida, F. (2021). Implementasi Merdeka Belajar melalui Kampus Mengajar Perintis di Sekolah Dasar. Metodik Didaktik: Jurnal Pendidikan Ke-SD-An, 16(2), 102-107. https://doi.org/10.17509/md.v16i2.30125

[28] Zahroh, S., \& Pontoh, R. S. (2021). Education as an important aspect to determine human development index by province in Indonesia. Journal of Physics: Conference Series, 1722(1). $\quad$ https://doi.org/10.1088/1742$\underline{6596 / 1722 / 1 / 012106}$ 